\title{
Update of cardiovascular autonomic neuropathy in patients with diabetes
}

Actualități despre neuropatia autonomă cardiovasculară la pacienții cu diabet zaharat

\author{
Andra-Elena Nica1,2, Carmen Dobjanschi1,2, Oana Andreea Parlițeanu1,3, \\ Emilia Rusu ${ }^{1,2}$, Gabriela Radulian ${ }^{1}$ \\ ${ }^{1}$ Universitatea de Medicină și Farmacie „Carol Davila“, Bucureşti, România \\ 2Spitalul Clinic „Nicolae Malaxa“, Bucureşti, România \\ ${ }^{3}$ Clinica Sanamed Hospital, Bucureşti, România
}

\begin{abstract}
The burden of diabetic cardiovascular autonomic neuropathy (CAN) is expected to increase due to the diabetes epidemic and its early and widespread appearance. CAN has a definite prognostic role for mortality and cardiovascular morbidity. Putative mechanisms for this are tachycardia, QT interval prolongation, orthostatic hypotension, reverse dipping, and impaired heart rate variability, while emerging mechanisms like inflammation support the pervasiveness of autonomic dysfunction. Efforts to overcome CAN under-diagnosis are: by promoting screening for symptoms and signs; by simplifying cardiovascular reflex tests.
\end{abstract}

Keywords: cardiovascular autonomic neuropathy, cardiovascular reflex tests, diabetes mellitus

\section{REZUMAT}

Prevalența neuropatiei cardiovasculare autonome diabetice (NAC) este de așteptat să crească din cauza epidemiei de diabet și a apariției sale timpurii și răspândite. NAC are un rol prognostic definit pentru mortalitate și morbiditate cardiovasculară. Mecanismele implicate în această patologie sunt tahicardia, prelungirea intervalului QT, hipotensiunea ortostatică, reverse dipping și variabilitatea ritmului cardiac. Prin promovarea screening-ului pentru simptome și semnele NAC și prin efectuarea testelor de reflex cardiovascular se poate depăși problema subdiagnosticării NAC.

Cuvinte cheie: neuropatie autonomă cardiovasculară, teste de reflex cardiovascular, diabet zaharat

\section{INTRODUCERE}

Evaluarea NAC permite tratarea manifestărilor sale, stratificarea riscului cardiovascular și adaptarea țintelor terapeutice. Factorii de risc pentru NAC sunt în principal controlul glicemic în cazul diabetului zaharat de tip 1 (DZ1) și, hipertensiunea arterială, dislipidemia și obezitatea în cazul diabetului zaharat de tip 2 (DZ2). Datele preliminare atrag atenția asupra variabilității glicemice, modificărilor vitaminei B12 și $\mathrm{D}$, stresului oxidativ, inflamației și biomarkerilor genetici. Controlul glicemic previne NAC în DZ1, în timp ce intervenția multifactorială ar putea fi eficientă în DZ2.

În plus față de vârstă și durata diabetului, alte corelații clinice stabilite sau predictori ai NAC sunt controlul glicemic, prezența retinopatiei, nefropatiei și polineuropatiei diabetice [1], în special în DZ1 [2]. De asemenea, a fost raportat din ce în ce mai mult rolul mai multor factori de risc cardiovasculari: hipertensiune arterială, fumat, LDL colesterol, HDL colesterol, trigliceride, greutate corporală, indicele de masă corporală (IMC), circumferința taliei, niveluri ridicate de insulină în DZ2, antecedente de boli cardiovasculare [2]. Stu- 
diile longitudinale în DZ2 au confirmat rolul predictiv independent de vârstă, retinopatie, nefropatie, hemoglobină glicată (HbA1c), IMC și trigliceride [3].

Mai recent, studii transversale au documentat asocierea NAC cu niveluri scăzute de vitamina B12 în DZ2 [4], atât nivel scăzut [5], cât și nivel ridicat de vitamina D în DZ1 și DZ2 [5] și cu niveluri scăzute de bilirubină în DZ2, așa cum a fost obținut într-o populație mare din Coreea [6].

Având în vederea creșterii incidentei diabetului, NAC este o complicație obişnuită, începe timpuriu în DZ2 şi are corelații multiple şi noi. Pacienții cu un risc mai mare de NAC sunt cei cu o vârstă mai mare, o durată mai lungă de evoluție a bolii, un control glicemic slab, dar şi cei cu complicații microvasculare (polineuropatie diabetică, retinopatie și nefropatie), și alți factori de risc cardiovascular în special obezitate, dislipidemie și hipertensiune arterială în DZ2.

În contextul pandemiei COVID-19, au fost efectuate mai multe studii care au încercat să evidențieze legătura dintre infecția SARS-CoV-2 și disfuncția autonomă cardiovasculară la pacienții cu diabet zaharat preexistent. S-a constatat că, în rândul pacienților diagnosticaţi cu forme asimptomatice până la moderate ale infecției cu coronavirus, este prezentă o activitate parasimpatică crescută, independentă de vârsta, sexul și comorbidităţile pacienților. De asemenea, frecvența cardiacă minimă și maximă, evaluată în cadrul testelor Ewing, a fost semnificativ mai scăzută în rândul pacienților cu COVID-19, în comparație cu subiecții sănătoși neinfectați. În schimb, într-o analiză subgrup a subiecților pozitivi, variabilitatea frecvenței cardiace nu a fost diferită în rândul pacienților asimptomatici, cu forme ușoare sau moderate [7].

La pacienții cu COVID-19, cu afecțiunile preexistente caracterizate prin activitate simpatică excesivă (de exemplu, hipertensiune arterială, diabet, boli cardiovasculare), combinația de hipoxemie asociată cu pneumonie SARS-CoV-2, inflamație difuză și activitate simpatică crescută măreşte susceptibilitatea la aritmii cardiace letale [8].

La pacienții cu COVID-19, așa-numita furtună de citokine este presupusă a contribui la o tranziţie rapidă de la o stare compensată la o stare decompensată care necesită oxigenoterapie. În consecință, pacienţii cu COVID-19 cu sevraj parasimpatic ca urmare a comorbidităților pot prezenta un risc mai mare de a dezvolta creșteri marcate ale eliberării de citokine ca urmare a lipsei unui reflex antiinflamator neuro-vagal complet funcțional. În testele preclinice, stimularea nervului vagal duce la restabilirea echilibrului autonom și la reducerea nivelurilor de citokine proinflamatorii în bolile cardiace ischemice. Teoretic, stimularea vagală ar putea fi un instrument util pentru a aborda inflamaţia sistemică prin activarea reflexului inflamator neuronal la pacienții cu COVID-19 cu afecțiuni cardio-metabolice preexistente caracterizate prin dezechilibru autonom [9].

Diagnosticul de NAC confirmat este asociat cu un risc relativ de mortalitate de 3,65 într-o metaanaliză a 15 studii longitudinale publicate până în 2001 [10]. Studii mai recente care au inclus eșantioane mari de pacienți, EURODIAB pentru DZ1 şi ACCORD pentru DZ2, au documentat, în urma testării reflexelor cardiovasculare, că NAC este un predictor independent al mortalității de cauză cardiovasculară.

NAC a fost, de asemenea, asociată cu morbidităţi vasculare, în primul rând cu ischemie miocardică silenţioasă - aşa cum este documentat într-o metaanaliză [10] şi confirmată de Studiul de identificare a ischemiei la pacienții cu diabet asimptomatici (DIAD) - cu morbiditate cardiovasculară, cu tulburări cardiovasculare recurente, istoric de boli cardiovasculare și cu accident vascular cerebral în DZ2 [1]. Mai mulți subiecți cu NAC au prezentat evenimente cardiovasculare (fatale și nonfatale) comparativ cu cei fără NAC (25\% vs. $10 \%)$.

Prezența NAC a fost, de asemenea, asociată cu dezvoltarea cardiomiopatiei diabetice. Inervația autonomă este principalul mecanism extrinsec de reglare a frecvenței cardiace și a performanței cardiace. Deoarece neuropatia este observată inițial la nivelul fibrelor lungi, manifestările timpurii ale neuropatiei autonome diabetice tind să fie asociate cu diverse grade de denervare parasimpatică. Astfel, la debut, este în general acceptat că NAC este caracterizată printr-o creștere a tonusului simpatic [11]. La pacienții cu DZ1 s-a observat că disfuncția ventriculului stâng adesea precedă sau se instalează în absența bolii coronariene aterosclerotice sau a hipertensiunii. Alterarea funcției diastolice și a celei sistolice se observă la subiecții diabetici care nu prezintă NAC și, deseori, precedă apariția complicațiilor macrovasculare. S- a observat că disfuncția diastolică ce apare într-o etapă timpurie a DZ1 este asociată cu anomalii la nivelul funcției cardiace simpatice, așa cum a fost demonstrat prin utilizarea scintigrafiei cardiace. Într-un alt studiu, Sacre și colab. au observat că, la pacienții cu DZ2, atât disfuncția sistolică, cât și cea diastolică sunt asociate cu NAC [12]. Re- 
cent, au fost analizati peste 900 de pacienți cu DZ1 care fac parte din studiul DCCT/EDIC și s-a observat că prezența NAC este asociată cu creșterea masei ventriculului stâng și cu remodelarea cardiacă de tip concentric, evidențiate prin utilizarea IRM cardiac. Această asociere este independentă de vârstă, sex, tensiune arterială și alți factori.

NAC poate promova hipertrofia ventriculară stângă prin diverse mecanisme, inclusiv prin impactul său asupra echilibrului simpatovagal și baroreflexelor. Componenta vagală a reflexelor baroreceptoare reprezintă mecanismul major de protecție ce reglează frecvența cardiacă, volumul bătaie și tensiunea arterială (TA), în vederea diminuării stresului asupra peretelui miocardic [11]. Un reflex baroreceptor lezat se asociază cu scăderea tonusului simpatic, creșterea tensiunii arteriale sistolice, creșterea stresului la nivelul peretelui ventricular stâng, conducând la hipertrofie ventriculară stângă și creșterea riscului de apariție a insuficienței cardiace și a altor boli cardiovasculare [13]. Studiile în derulare ar putea contribui la clarificarea aspectelor ce țin de interacțiunile complexe dintre NAC și dezvoltarea cardiomiopatiei la pacienții cu diabet.

Mecanismele acestui risc de mortalitate și morbiditate asociate cu NAC rămân în mare parte necunoscute. O serie de anomalii cardiovasculare au fost găsite în asociere cu NAC. Ele pot reprezenta o formă de morbiditate în sine, cum ar fi ischemia miocardică silențioasă; un factor de risc recunoscut pentru mortalitate sau morbiditate (tahicardia de repaus, hipotensiunea ortostatică, prelungirea intervalului QT [QTi], afectarea sensibilității baroreflexe [BRS], nondipping, variația redusă a frecvenței cardiace); un dezechilibru al activității simpatovagale, denervarea simpatică, diminuarea vasodilatației mediate simpatic a arterelor coronare, dar și noi mecanisme precum creșterea rigidității arteriale și inflamație [1,14].

Tahicardia de repaus este cel mai puțin specific semn al NAC și poate reflecta, de asemenea, insuficiența vagală și/sau hiperactivitatea simpatică prezentă în boli cardiace, obezitate sau anemie. Tahicardia are o valoare prognostică la populația generală și diabetică. În studiul ADVANCE, realizat pe 11.140 de pacienți cu DZ2, o frecvență cardiacă în repaus mai mare a fost asociată cu un risc crescut de mortalitate pentru toate cauzele [15].

Hipotensiunea arterială ortostatică $(\mathrm{OH})$ este definită ca o scădere permanentă a TA sistolică de $20 \mathrm{mmHg}$ sau a TA diastolică de $10 \mathrm{mmHg}$ la subiecții normotensivi și o scădere a TA sistolică de $30 \mathrm{mmHg}$ la subiecții hipertensivi. O metaanaliză a 13 studii observaționale, incluzând 121.913 subiecți cu și fără diabet și hipertensiune arterială, cu o monitorizare mediană de 6 ani, a arătat că prevalența hipotensiunii ortostatice a fost asociată cu un risc crescut de deces cauzat de boala coronariană ischemică, insuficiență cardiacă și accident vascular cerebral, cu o estimare comună a riscului relativ pentru decesul total cauzat de 1,78 la pacienții cu vârstă mai mică de 65 de ani și 1,26 la subgrupul mai în vârstă. În mod similar, la pacienții cu diabet zaharat, $\mathrm{OH}$ crește cu $30 \%$ până la $100 \%$ riscul pentru mortalitatea asociată cu neuropatia parasimpatică [16].

Folosind monitorizarea TA ambulatorie cu ajutorul dispozitivului Holter de tensiune, putem identifica profilul de tensiune nondipping respectiv reverse dipping. O scădere a TA de la zi la noapte $<10 \%$ identifică nondipping și, respectiv, reverse dipping. Nondipping este mai frecventă în cazul pacienţilor cu diabet (39-62\%) decât în populația generală, iar reverse dipping este prezentă între 9\% și 30\% [16]. Reverse dipping este considerată un semn al NAC.

\section{EVALUAREA ŞI DIAGNOSTICUL NAC}

Metodele de evaluare a NAC în practica clinică includ evaluarea simptomelor și semnelor, efectuarea testelor Ewing și monitorizarea TA cu ajutorul dispozitivului Holter.

Metodele care evaluează variabilitatea frecvenței cardiace și senzitivitatea baroreflexă pot fi utilizate în domeniile clinice și de cercetare $[1,17]$.

Simptomele NAC sunt tahicardie, intoleranță la exercițiu fizic și simptome ale hipotensiunii ortostatice, cum ar fi vertij, vedere încețoșată și lipotimie la trecerea în ortostatism.

Deși ghidurile științifice [1] consideră simptomele autonome drept prima indicație de investigare la orice pacient cu diabet, pentru impactul lor potențial asupra calității vieții și pentru a obține un diagnostic diferențial, există o presupunere că, din cauza lipsei lor de specificitate, ele nu reprezintă un instrument util pentru diagnosticul NAC. $\mathrm{Cu}$ toate acestea, această idee a fost contestată de rezultatele obținute din rezultatul chestionarului Compus Autonomic Symptom Score 31 (COMPASS 31) [18]. Acesta a fost validat pentru diagnosticull NAC bazat pe testele Ewing și a arătat o precizie corectă a diagnosticului, cu o sensibilitate de $75 \%$ pentru NAC și $70 \%$ pentru NAC confirmată și o specificitate de $65 \%$ și, respectiv, $67 \%$ [19]. 
Tahicardia, hipotensiunea ortostatică, prelungirea QTi și reverse dipping sunt manifestări tipice ale NAC, care pot fi detectate cu ușurință în timpul evaluării clinice și pot avertiza medicul cu privire la prezența NAC. Sensibilitatea și specificitatea hipotensiunii ortostatice este de $31 \%$ şi $98 \%$, respectiv 28\% şi $86 \%$ pentru un QTi corectat, iar pentru reverse dipping $26 \%$ și $95 \%$. Consensul de la Toronto a recomandat screening-ul pentru simptomele hipotensiunii ortostatice la orice pacient diabetic (un test de hipotensiune ortostatică anual), în special la pacienții cu vârsta peste 50 de ani, hipertensivi, și evaluarea cu ajutorul testelor reflexe autonome cardiovasculare dacă este prezentă tahicardia inexplicabilă, prelungirea QTi și reverse dipping [1].

Testele reflexe autonome cardiovasculare măsoară frecvența cardiacă și răspunsul TA la manevrele fiziologice și reprezintă în continuare standardul de aur în testarea autonomă, așa cum a declarat Consensul de la Toronto [1] și au declarat societățile știinţifice neurologice.

În ceea ce privește întrebarea despre eficacitatea diagnosticului NAC în practica clinică, răspunsul este că evaluarea NAC la pacienții cu simptomatologie prezentă permite tratamente care vizează consecințele clinice ale NAC și poate oferi, de asemenea, o perspectivă asupra strategiei terapeutice generale [1].

La pacienții asimptomatici, detectarea NAC oferă informații utile pentru stratificarea riscului complicațiilor legate de diabet, morbiditate și mortalitate cardiovasculară, pentru definirea și adaptarea țintelor terapiei diabetului [1]. Într-un studiu efectuat pe 894 de participanţi cu DZ2 urmăriţi timp de 9,5 ani, procentul episoadelor de hipoglicemie severă a crescut de la 5,4\% la pacienții fără NAC la 17,2\% la pacienții cu NAC în formă ușoară și $22,7 \%$ la pacienții cu NAC severă. NAC severă a fost asociată cu un raport de risc ajustat de 2,43 pentru dezvoltarea hipoglicemiei severe [12].

$\mathrm{O}$ altă metodă de diagnostic este reprezentată de testele de evaluare a funcţiei sudomotorii, care au fost susținute ca măsuri de diagnostic pentru NAC, cu avantajul suplimentar al evaluării fibrelor nervoase mici la membrele inferioare.

Un studiu efectuat pe o populaţie de pacienți chinezi cu DZ2 a evaluat diferența dintre testele de evaluare a funcției sudomotorii și testele de reflexe cardiovasculare. În urma efectuării testului de sudorație, se obține un scor de risc cardiovascular, care s-a asociat semnificativ statistic cu prezența NAC. Analiza regresiei multiple, care a inclus variabile semnificative, a arătat $\mathrm{o}$ asociere indepen- dentă a scorului de risc pentru NAC obținut în urma efectuării testului de sudorație cu variabilitatea frecvenței cardiace în hiperpnee, dar și cu vârsta $(p=0,00)[20]$.

\section{TRATAMENT - OPTIMIZAREA STILULUI DE VIAŢĂ}

Se pare că optimizarea stilului de viață are un efect benefic asupra funcției autonome cardiovasculare. Prima documentare a fost furnizată de studiul Programului de prevenire a diabetului, în care au fost incluşi 2.980 de participanţi cu diabet zaharat şi în care a fost demonstrat că optimizarea stilului de viaţă a îmbunătățit ritmul cardiac, HRV și lungimea QTi [21].

O serie de studii au demonstrat că și o pierdere în greutate moderată, secundară unei restricții calorice, poate îmbunătăți modularea autonomă cardiacă prin creșterea indicilor de timp și domenii de frecvență ale HRV, ameliorarea echilibrului simpatovagal și BRS și scăderea tonusului simpatic la persoanele normotensive cu obezitate sau la pacienții cu sindrom metabolic [22]. Cinci studii au evaluat efectele scăderii în greutate la pacienţii cu diabet, cu o monitorizare a greutății la 12 luni și cu o pierdere în greutate de cel puțin 10\%. În aceste studii, pierderea în greutate a fost asociată cu o creștere a indicilor parasimpatici de HRV și îmbunătățirea echilibrului simpatovagal, iar întrun studiu, de asemenea, cu o îmbunătătire a reflexelor autonome cardiovasculare.

Având în vedere că obezitatea și DZ2 precoce sunt asociate cu HRV redus și cu hiperactivitate sau prevalență simpatică, studiile efectuate la persoanele obeze, în principal, fără diabet documentează că pierderea în greutate este asociată cu îmbunătăţirea HRV.

Efectele exerciţiului fizic au fost evaluate întrun studiu care a inclus 50 de bărbaţi cu DZ2 şi care a demonstrat că antrenamentul combinat la (aerobic și rezistență) timp de 12 luni a fost asociat cu îmbunătățirea BRS (dar nu și cu îmbunătățirea HRV) [23].

O strategie preventivă eficientă pentru NAC ar trebui să includă controlul greutății, activitatea fizică, renunțarea la fumat, adoptarea dietelor sănătoase, controlul glicemic, controlul factorilor de risc cardiovascular precum TA și dislipidemie și o abordare comportamentală care vizează controlul stresului și, nu în ultimul rând, educație [1]. În acest sens, Consensul de la Toronto a concluzionat că intervenția asupra stilului de viață poate îmbunătăți HRV în diabetul zaharat şi prediabet. 
ADA recomandă luarea în considerare a modificărilor stilului de viață pentru a îmbunătăți NAC la pacienții cu diabet zaharat [24].

\section{TRATAMENT FARMACOLOGIC}

Există dovezi clare pentru eficacitatea tratamentului intensiv al hiperglicemiei în DZ1 cu beneficiu prelungit (studiu EDIC) [25], în timp ce eficacitatea este evidentă doar în stabilirea unei strategii multifactoriale în DZ2 [26].

ADA recomandă optimizarea controlului glucozei cât mai devreme posibil pentru a preveni sau întârzia dezvoltarea NAC în DZ1 și, de asemenea, recomandă luarea în considerare a unei abordări multifactoriale care vizează glicemia și alți factori de risc pentru a preveni NAC în DZ2 [24].

Deși un efect benefic al metforminei asupra echilibrului simpatic a fost documentat în DZ2 și explicat în principal prin scăderea concomitentă a acizilor grași liberi din plasmă și a rezistenței la insulină, un punct interesant în epoca actuală este reprezentat de noi clase de medicamente care acţionează prin scăderea nivelului de glucoză, dar și prin ameliorarea sistemului nervos autonom.

\section{Inhibitori ai transportorului sodiu glucoză 2 (SGLT2i)}

Tinta SGLT2i este aceeași ca și la nervii simpatici - celulele epiteliale tubulare renale, unde fibrele simpatice eferente promovează reabsorbția tubulară a sodiului [27,28]. Astfel, legătura dintre sistemul nervos simpatic și reglarea SGLT2 a fost concepută pe baza creșterii accentuate a expresiei SGLT2, indusă de neurotransmițătorul simpatic noradrenalină în celulele tubulare renale umane, și a acțiunii de inhibare a SGLT2i dapaglifozin asupra expresiei tirozinei hidroxilazei și noradrenalinei la nivel renal şi cardiac. Mai mult decât atât, reducerea TA după 4 zile de tratament cu empaglifozină la 22 de pacienți cu DZ2 tratați cu metfor-

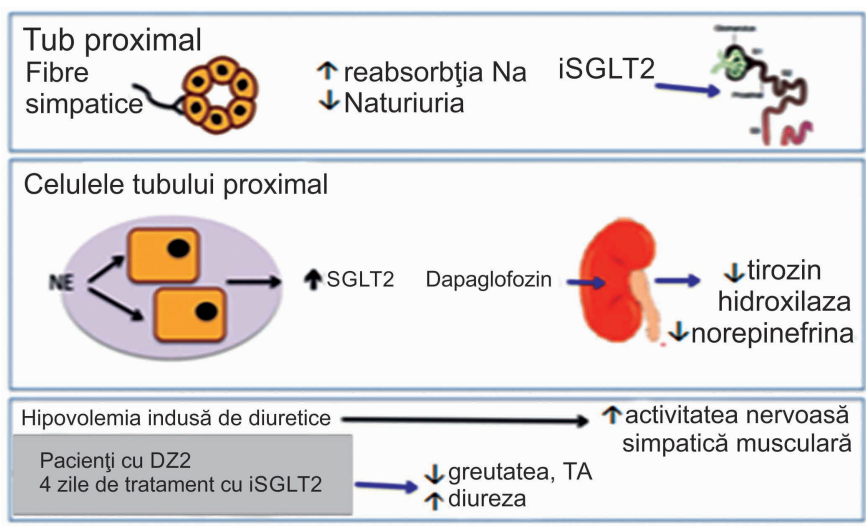

min nu a dus la o creștere a activităţii nervoase simpatice musculare ca răspuns la efectul diuretic, sugerând cel puțin o modulare de scădere a activității simpatice [29].

\section{Agonişti ai receptorilor de GLP-1 (GLP1-RA)}

Descoperirile experimentale la şoareci documentează că administrarea GLP1-RA a crescut ritmul cardiac, a redus HRV și a crescut activitatea simpatică [31]. La indivizii sănătoși, administrarea de GLP1-RA a produs o creștere a ritmului cardiac şi a activităţii nervoase simpatice musculare. În studiile clinice, GLP1-RA au crescut ritmul cardiac în jur de 3 bpm [32] și au contribuit la scăderea BP sistolică, precum şi scăderea riscului cardiovascular. Mai mult, într-un studiul a 28 de pacienți cu DZ2, exenatida cu eliberare prelungită (ER) o dată pe săptămână a fost asociată cu creșterea ritmului cardiac [33]. Creșterea ritmului cardiac se crede că are mai multe cauze, printre care: o creștere a activității simpatice atât direct [34], cât și mediat de creșterea de insulină endogenă determinată de GLP1 [31]; o acțiune asupra receptorilor GLP1 prezenți la nivelul cardiomiocitelor [35].

$\mathrm{O}$ serie de efecte benefice au fost atribuite acidului $\alpha$-lipoic, inclusiv o îmbunătăţire a homeostazei glucozei și a profilului lipidic, o acțiune antiinflamatoare și capacitatea de a reduce stresul oxidativ, precum și o creștere a producției de oxid nitric, dar și în activitatea $\mathrm{Na}+$ / K + -ATPază și o reducere a glicozilării proteice [37].

$\mathrm{Cu}$ toate acestea, există tratamente pentru formele clinice ale NAC. În ceea ce privește hipotensiunea ortostatică, tratamentul este recomandat doar în forme simptomatice, cu scopul de a reduce la minimum simptomele și de a crește calitatea vieții de zi cu zi. Măsurile nonfarmacologice sunt adesea suficiente.

Tratamentul hipertensiunii arteriale poate avea o dificultate deosebită ca urmare a necesității de a scădea TA fără a agrava hipotensiunea ortostatică.
FIGURA 1. Relația dintre iSGT2 şi sistemul nervos simpatic [30]. NE = norepinefrină; $T A=$ tensiune arterială 


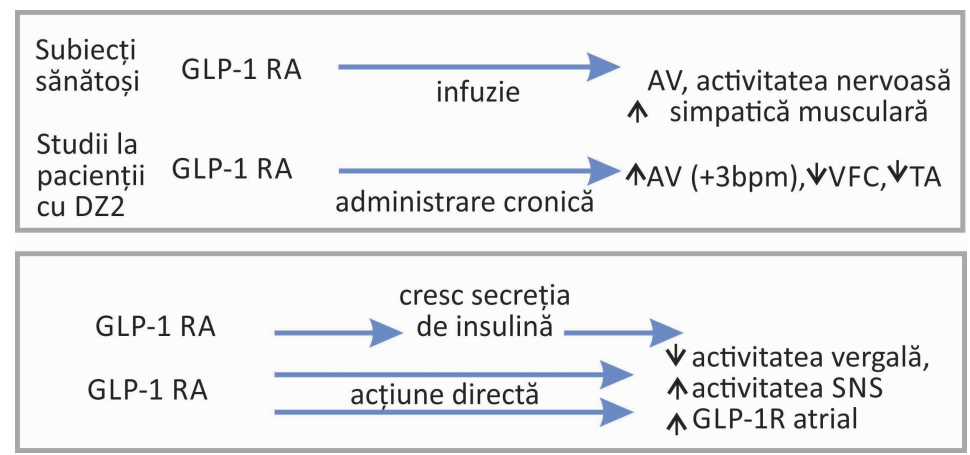

FIGURA 2. Relația dintre glucagon like peptid 1 receptor agonist şi sistemul nervos simpatic [36]

GLP-1 RA = glucagon like peptid 1 receptor agonist, $A V$ - alura ventriculară; $V F C=$ variabilitatea frecvenței cardiace, $T A=$ tensiunea arterială,

$S N S=$ sistem nervos simpatic, GLP-1 R atrial = receptori de GLP-1 de la nivel atrial

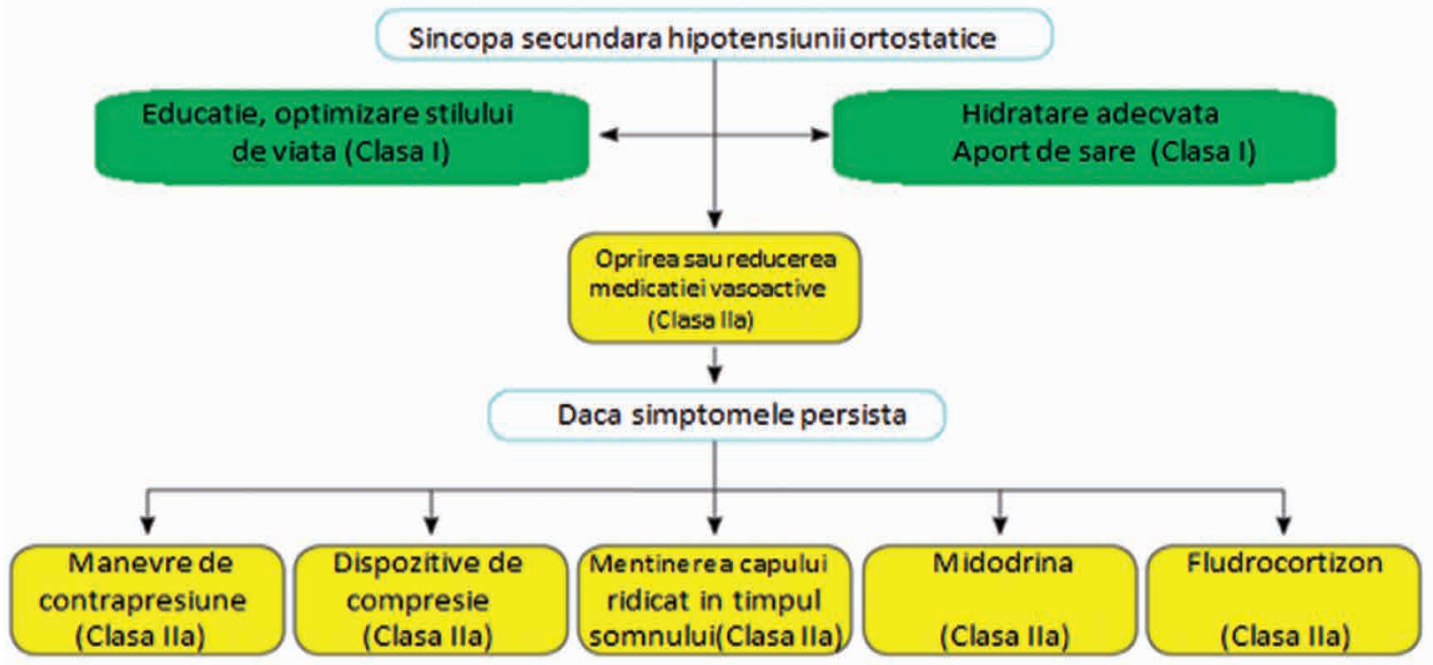

FIGURA 3. Recomandări de tratament pentru hipotensiunea ortostatică - adaptat după ESC 2018 [37]

S-a confirmat ca tratamentul intensiv în DZ1 întârzie apariţia NAC, în timp ce în DZ2 există o dovadă limitată pentru intervenția multifactorială. Datele obţinute în urma efectuării studiilor cu SGLT2i introduc posibilitatea unui efect modulator asupra funcției autonome cardiovasculare. Pe de altă parte, tratamentul simptomatic al corelațiilor clinice ale NAC precum hipotensiunea ortistatică și hipertensiunea arterială nocturnă este disponibil și se recomandă a fi utilizat oricând se consideră că aduce un beneficiu pacienților.

\section{CONCLUZII}

NAC poate să apară foarte devreme, încă din stadiul de prediabet, și este frecvent subdiagnosticată, iar prevalența acestei afecțiuni este în creștere.
Factorii de risc asociați NAC ar putea deveni noi ținte pentru prevenirea acestor complicații cronice ale diabetului zaharat. Există date care confirmă semnificația prognostică a NAC și dovezi importante ale rolului său central în afectarea cardiovasculară. NAC trebuie să fie abordată multifactorial atât în practica medicală, cât și în cercetări ulterioare.

Existența unui continuum fiziopatologic în boli precum DZ și HTA, care sunt caracterizate printr-o activitate simpatică crescută, poate predispune la creșteri marcate ale activității simpatice în timpul infecției cu COVID-19. Astfel, putem afirma că această caracteristică comună este un factor important care contribuie la creșterea morbidității și mortalității după infecția cu SARS-CoV-2 la pacienții cu afecțiuni preexistente. 


\section{BIBLIOGRAFIE}

1. Spallone V, Ziegler D, Freeman R, Bernardi L, Frontoni S, Pop-Busui $\mathrm{R}$, et al.; Toronto Consensus Panel on Diabetic Neuropathy. Cardiovascular autonomic neuropathy in diabetes: clinical impact, assessment, diagnosis, and management. Diabetes Metab Res Rev. 2011 Oct;27(7):639-53.

2. Fleischer J, Yderstraede $K$, Gulichsen E, Jakobsen PE, Lervang $H H$, Eldrup E, Nygaard H, Tarnow L, Ejskjaer N. Cardiovascular autonomic neuropathy is associated with macrovascular risk factors in type 2 diabetes: new technology used for routine large-scale screening adds new insight. J Diabetes Sci Technol. 2014 Jul;8(4):874-80.

3. Andersen ST, Witte DR, Fleischer J, Andersen H, Lauritzen T, Jørgensen ME, Jensen TS, Pop-Busui R, Charles M. Risk Factors for the Presence and Progression of Cardiovascular Autonomic Neuropathy in Type 2 Diabetes: ADDITION-Denmark. Diabetes Care. 2018 Dec;41(12):2586-2594.

4. Hansen CS, Jensen JS, Ridderstråle M, Vistisen D, Jørgensen ME, Fleischer J. Vitamin B12 deficiency is associated with cardiovascular autonomic neuropathy in patients with type 2 diabetes. J Diabetes Complications. 2017 Jan;31(1):202-208.

5. Hansen CS, Fleischer J, Vistisen D, Ridderstråle M, Jensen JS, Jørgensen ME. High and low vitamin D level is associated with cardiovascular autonomic neuropathy in people with Type 1 and Type 2 diabetes. Diabet Med. 2017 Mar;34(3):364-371.

6. Chung JO, Cho DH, Chung DJ, Chung MY. Physiological serum bilirubin concentrations are inversely associated with the prevalence of cardiovascular autonomic neuropathy in patients with type 2 diabetes. Diabet Med. 2014 Feb;31(2):185-91.

7. Kaliyaperumal D, Rk K, Alagesan M, Ramalingam S. Characterization of cardiac autonomic function in COVID-19 using heart rate variability: a hospital based preliminary observational study. J Basic Clin Physiol Pharmacol. 2021 Mar 12;32(3):247-253.

8. Del Rio R, Marcus NJ, Inestrosa NC. Potential Role of Autonomic Dysfunction in COVID-19 Morbidity and Mortality. Front Physiol. 2020 Oct 16;11:561749.

9. Tracey KJ. The inflammatory reflex. Nature. 2002 Dec 19-26; 420(6917):853-9.

10. Vinik Al, Ziegler D. Diabetic cardiovascular autonomic neuropathy. Circulation. 2007 Jan 23;115(3):387-97.

11. Pop-Busui R. What do we know and we do not know about cardiovascular autonomic neuropathy in diabetes. $J$ Cardiovasc Transl Res. 2012 Aug;5(4):463-78.

12. Sacre JW, Franjic B, Jellis CL, Jenkins $C$, Coombes JS, Marwick TH. Association of cardiac autonomic neuropathy with subclinical myocardial dysfunction in type 2 diabetes. JACC Cardiovasc Imaging. 2010 Dec;3(12):1207-15.

13. La Rovere MT, Pinna GD, Maestri R, Robbi E, Caporotondi A, Guazzotti G, Sleight P, Febo O. Prognostic implications of baroreflex sensitivity in heart failure patients in the beta-blocking era. J Am Coll Cardiol. 2009 Jan 13;53(2):193-9.

14. Abboud FM, Singh MV. Autonomic regulation of the immune system in cardiovascular diseases. Adv Physiol Educ. 2017 Dec 1; 41(4):578-593.

15. Hillis GS, Woodward M, Rodgers A, Chow CK, Li Q, Zoungas S, Patel A, Webster R, Batty GD, Ninomiya T, Mancia G, Poulter NR, Chalmers J. Resting heart rate and the risk of death and cardiovascular complications in patients with type 2 diabetes mellitus. Diabetologia. 2012 May;55(5):1283-90.

16. Spallone V. Blood Pressure Variability and Autonomic Dysfunction. Curr Diab Rep. 2018 Oct 25;18(12):137.

17. Bernardi L, Spallone V, Stevens M, Hilsted J, Frontoni S, Pop-Busui $\mathrm{R}$, Ziegler D, Kempler P, Freeman R, Low P, Tesfaye S, Valensi P; Toronto Consensus Panel on Diabetic Neuropathy. Methods of investigation for cardiac autonomic dysfunction in human research studies. Diabetes Metab Res Rev. 2011 Oct;27(7):654-64.

18. Sletten DM, Suarez GA, Low PA, Mandrekar J, Singer W. COMPASS 31: a refined and abbreviated Composite Autonomic Symptom Score. Mayo Clin Proc. 2012 Dec;87(12):1196-201.

19. Greco C, Di Gennaro F, D’Amato C, Morganti R, Corradini D, Sun A, Longo S, Lauro D, Pierangeli G, Cortelli P, Spallone V. Validation of the Composite Autonomic Symptom Score 31 (COMPASS 31) for the assessment of symptoms of autonomic neuropathy in people with diabetes. Diabet Med. 2017 Jun;34(6):834-838.

20. Yuan T, Li J, Fu Y, Xu T, Li J, Wang X, Zhou Y, Dong Y, Zhao W. A cardiac risk score based on sudomotor function to evaluate cardiovascular autonomic neuropathy in asymptomatic Chinese patients with diabetes mellitus. PLoS One. 2018 Oct 3;13(10):e0204804

21. Carnethon MR, Prineas RJ, Temprosa M, Zhang ZM, Uwaifo G, Molitch ME; Diabetes Prevention Program Research Group. The association among autonomic nervous system function, incident diabetes, and intervention arm in the Diabetes Prevention Program. Diabetes Care. 2006 Apr;29(4):914-9.

22. Guarino D, Nannipieri M, lervasi G, Taddei S, Bruno RM. The Role of the Autonomic Nervous System in the Pathophysiology of Obesity. Front Physiol. 2017 Sep 14;8:665.

23. Loimaala A, Huikuri HV, Kööbi T, Rinne M, Nenonen A, Vuori I. Exercise training improves baroreflex sensitivity in type 2 diabetes. Diabetes. 2003 Jul;52(7):1837-42.

24. Pop-Busui R, Boulton AJ, Feldman EL, Bril V, Freeman R, Malik RA, Sosenko JM, Ziegler D. Diabetic Neuropathy: A Position Statement by the American Diabetes Association. Diabetes Care. 2017 Jan;40(1):136-154.

25. Martin CL, Albers JW, Pop-Busui R; DCCT/EDIC Research Group. Neuropathy and related findings in the diabetes control and complications trial/epidemiology of diabetes interventions and complications study. Diabetes Care. 2014;37(1):31-8.

26. Gæde P, Oellgaard J, Carstensen B, Rossing P, Lund-Andersen H, Parving $\mathrm{HH}$, Pedersen $\mathrm{O}$. Years of life gained by multifactorial intervention in patients with type 2 diabetes mellitus and microalbuminuria: 21 years follow-up on the Steno-2 randomised trial. Diabetologia. 2016 Nov;59(11):2298-2307.

27. DiBona GF, Esler M. Translational medicine: the antihypertensive effect of renal denervation. Am J Physiol Regul Integr Comp Physiol. 2010 Feb;298(2):R245-53.

28. Ghezzi C, Loo DDF, Wright EM. Physiology of renal glucose handling via SGLT1, SGLT2 and GLUT2. Diabetologia. 2018 Oct;61(10):2087-2097.

29. Matthews VB, Elliot RH, Rudnicka C, Hricova J, Herat L, Schlaich MP. Role of the sympathetic nervous system in regulation of the sodium glucose cotransporter 2. J Hypertens. 2017 Oct;35(10):2059-2068.

30. Rahman A, Fujisawa Y, Nakano D, Hitomi H, Nishiyama A. Effect of a selective SGLT2 inhibitor, luseogliflozin, on circadian rhythm of sympathetic nervous function and locomotor activities in metabolic syndrome rats. Clin Exp Pharmacol Physiol. 2017 Apr;44(4):522-525.

31. Valensi $P$, Chiheb S, Fysekidis M. Insulin- and glucagon-like peptide-1-induced changes in heart rate and vagosympathetic activity: why they matter. Diabetologia. 2013 Jun;56(6):1196-200.

32. Sun F, Wu S, Guo S, Yu K, Yang Z, Li L, Zhang Y, Quan X, Ji L, Zhan S. Impact of GLP-1 receptor agonists on blood pressure, heart rate and hypertension among patients with type 2 diabetes: A systematic review and network metaanalysis. Diabetes Res Clin Pract. 2015 Oct;110(1):26-37.

33. Cacciatori V, Zoppini G, Bellavere F, Rigolon R, Thomaseth K, et al. Long-Acting GLP-1 Receptor Agonist Exenatide Influence on the Autonomic Cardiac Sympatho-Vagal Balance. J Endocr Soc. 2017 Nov 6;2(1):53-62.

34. Smits MM, Muskiet MH, Tonneijck L, Hoekstra T, Kramer MH, Diamant $\mathrm{M}$, van Raalte $\mathrm{DH}$. Exenatide acutely increases heart rate in parallel with augmented sympathetic nervous system activation in healthy overweight males. Br J Clin Pharmacol. 2016 Apr;81(4):613-20.

35. Nakatani Y, Kawabe A, Matsumura M, Aso Y, Yasu T, Banba N, Nakamoto T. Effects of GLP-1 Receptor Agonists on Heart Rate and the Autonomic Nervous System Using Holter Electrocardiography and Power Spectrum Analysis of Heart Rate Variability. Diabetes Care. 2016 Feb;39(2):e22-3.

36. Golbidi S, Badran M, Laher I. Diabetes and alpha lipoic Acid. Front Pharmacol. 2011 Nov 17;2:69.

37. Brignole M, Moya A, de Lange FJ, Deharo JC, Elliott PM, et al.; ESC Scientific Document Group. 2018 ESC Guidelines for the diagnosis and management of syncope. Eur Heart J. 2018 Jun 1;39(21):1883-1948. 